\title{
DAMPAK PERKULIAHAN PRAKTIKUM HISAB AWAL WAKTU SALAT DAN ARAH KIBLAT TERHADAP KEHIDUPAN BERAGAMA MAHASISWA
}

\author{
Agus Solikin \\ UIN Sunan Ampel Surabaya \\ agussolikin2@gmail.com
}

\begin{abstract}
ABSTRAK
Salat yang merupakan kewajiban bagi setiap Muslim dalam pelaksanaannya senantiasa mengikuti aturan yang ada. Aturan tersebut diantaranya terkait dengan aturan waktu pelaksanaan dan arah kiblatnya. Dua aturan tersebut dalam prodi ilmu falak dikaji dalam mata kuliah praktikum hisab awal waktu salat dan arah kiblat.

Berangkat dari tersebut di atas, maka penelitian ini dirancang dengan tujuan untuk mengetahui Evaluasi Dampak Perkuliahan Praktikum Hisab Awal Waktu Salat dan Arah Kiblat Terhadap Kehidupan Beragama Mahasiswa . Guna mencapai tujuan tersebut, maka penelitian ini dirancang dalam penelitian kuantitatif deskriptif. Subjek dalam penelitian ini adalah mahasiswa prodi IImu Falak Fakultas Syariah Dan Hukum UIN Sunan Ampel Surabaya tahun akademik 2017/2018.

Selaras dengan tujuan tersebut, dan berdasarkan analisis dalam penelitian yang telah dilakukan, dapat disimpulkan bahwa mata kuliah praktikum hisab awal waktu salat dan arah kiblat terhadap memberikan dampak kepada mahasiswa dalam kehidupan beragama paling kuat dalam pengetahuan, dibandingkan dalam wilayah untuk melakukan sesuai dengan teori yang dipelajari ketika salat.
\end{abstract}

Katakunci: Dampak, Praktikum Hisab Awal Waktu Salat Dan Arah Kiblat, Kehidupan beragama mahasiswa

\section{ABSTRACT}

Prayer (Salat) which is an obligation for every Muslim in it's implementation always follows the existing rules. Among these rules are related to the rules of implementation time and Qibla direction. The two rules in the astronomy study program are studied in the practice of hisab at the beginning of prayer time and the direction of Qibla.

Departing from the above, this study was designed with the aim to find out the Evaluation of the Impact of Hisab Preliminary Lecture Practices and the Qibla Direction Toward Student Religious Life. In order to achieve this goal, this study was designed in descriptive quantitative research. Subjects in this study were students of the Falak Science Study Program Faculty of Sharia and Law UIN Sunan Ampel Surabaya in the academic year 2017/2018.

In line with these objectives, and based on the analysis in research that has been done, it can be concluded that the practical reckoning course at the beginning of the prayer times and the direction of Qibla towards giving impact to students in religious life is most powerful in knowledge, compared to the region to do according to the theory being studied when praying (salat).

Keywords: Impact, Practical Practices of Preliminary Prayer Times and Qibla Direction, Religious Life of Students

\section{PENDAHULUAN}

Umat Islam memiliki kewajiban

sehari semalam untuk salat lima waktu, dan ketika menjalankan kewajibannya tersebut, ada dua hal yang tidak bisa dilakukan secara 
sembarangan. Dua hal tersebut yaitu terkait dengan arah kiblat dan waktu salat yang harus dilakukan secara benar sesuai dengan tuntunan yang ada.

Terkait dengan arah kiblat dalam pelaksanaan salat, pada pada dasarnya yaitu penentuan arah dari titik tempat untuk melaksanakan salat menuju ke sebuah titik yang menjadi acuan atau pusat yaitu ka'bah. Sebagaiamana firman Allah dalam QS. Al-Baqarah (2) ayat 144.

"Sungguh Kami (sering) melihat mukamu menengadah ke langit, maka sungguh Kami akan memalingkan kamu ke kiblat yang kamu sukai. Palingkanlah mukamu ke arah Masjidil Haram. Dan di mana saja kamu berada, palingkanlah mukamu ke arahnya. Dan sesungguhnya orangorang (Yahudi dan Nasrani) yang diberi Al Kitab (Taurat dan Injil) memang mengetahui, bahwa berpaling ke Masjidil Haram itu adalah benar dari Tuhannya; dan Allah sekalikali tidak lengah dari apa yang mereka kerjakan." (Departemen Agama, 2005:23)

Berikutnya, terkait dengan waktu salat secara garis besar sebagaimana dijelaskan dalam alQuran Surah An-Nisa' ayat 103 bahwa waktu-waktu pelaksanaannya telah ditentukan. Walaupun tidak dijelaskan secara terperinci di dalam al-Quran namun secara isyarat alQuran telah menentukannya, diantaranya dalam QS Q.S. al-Isra ayat 78 , Q.S. Hud ayat 114 , dan Q.S. Thaha ayat 130 . Sedangkan penjelasan tentang waktu salat diterangkan secara rinci dalam hadits-hadits Nabi sebagaimana yang ditulis oleh Ibn Khuzaimah (1970: 168):

Malaikat Jibril a. s. pernah menjadi imamku dua kali, Pada kali pertama, salat Zuhur, dilakukan ketika bayangan sebesar tali sepatu. Kemudian salat Asar ketika bayangan seukuran dengan benda aslinya. Dilanjutkan dengan salat Magrib ketika Matahari terbenam dan orangorang berbuka puasa. Salat Isya ketika ketika mega merah menghilang dan diakhiri dengan salat Subuh kala fajar menyingsing dan bagi mereka yang hendak puasa dilarang makan. Dan pada salat yang kedua kalinya, salat Zuhur dilakukan kala bayangan seukuran dengan aslinya (sama seperti waktu Asar pada sore hari). Dilanjutkan dengan salat Asar ketika bayangan ukurannya dua kali lipat dari aslinya dan salat Magrib sama seperti pada salat Magrib kali pertama. Dilanjutkan dengan salat Isya pada akhir sepertiga malam dan salat Subuh ketika bumi sudah mulai kelihatan. Kemudian Jibril menghampiriku dan berkata, "Wahai Muhammad, ini adalah waktu salat yang dilakukan oleh para nabi sebelum kamu. Waktu salat adalah di antara ketentuan yang ada.

Selaras dengan sebelumnya, membahas tentang penetuan arah kiblat, sejatinya tidak lain dalam kajian ilmu falak dipahami sebagai proses melakukan sebuah perhitungan untuk menentukan jarak terdekat antara dua tempat dalam 
bola Bumi yaitu tempat yang akan dihitung arah kiblatnya dengan ka'bah. Jarak terdekat ini, dalam kajiannya familiar dengan istilah jarak sferis (Kusdiono, 2002:5). Sedangkan terkait dengan waktu salat, sejatinya guna mengetahui sudah atau belum masuk tanda masuknya waktu salat tersebut bisa dilakukan dengan pengamatan posisi Matahari secara langsung, maupun tanda alam lain yang mengindikasikan masuknya waktu salat, seperti fajar atau mega. Namun, karena perkembangan sains dan ilmu pengetahuan, maka tandatanda alam tersebut bisa dihitung dan ditentukan waktunya (Nawawi, 2010:23)

Berikutnya, terkait dengan arah kiblat dan waktu salat tersebut, Prodi IImu Falak Fakultas Syariah dan Hukum UIN Sunan Ampel Surabaya, memfasilitasi mahasiswanya dengan menjadikannya mata kuliah wajib yaitu mata kuliah hisab awal waktu salat dan arah kiblat, serta mata kuliah praktikum hisab awal waktu salat dan arah kiblat. Dua mata kuliah tersebut, diberikan dalam semester yang sama, yaitu semester tiga.

Hadirnya dua mata kuliah tersebut, mengindikasikan bahwa mahasiswa prodi ilmu falak secara kompetensi keilmuan paham secara teori terkait dengan awal waktu salat dan arah kiblat, baik secara dasar hukum maupun hisab atau perhitungannya. Sedangkan mata kuliah praktikum awal waktu salat dan arah kiblat, mengindikasikan bahwa prodi ilmu falak berharap mahasiswanya bukan hanya paham secara teori, namun juga harus paham secara aplikatif.

Berdasarkan uraian tersebut diatas, maka mahasiswa yang telah mengambil dua mata kuliah tersebut idealnya dalam melaksanakan ibadah salat, terkait dengan awal waktu salat dan arah kiblat senantiasa berusaha untuk sesuai dengan apa yang telah dipelajarinya, sebagaimana yang disampaikan oleh Muzakki (2015:5758) bahwa nilai yang ditransmisikan kepada mahasiswa tidak hanya berhenti menjadi kekayaan kognitif mahasiswa, melainkan juga mengejawantah dalam kehidupan keseharian mahasiswa.

Sama dengan yang dituliskan oleh Muzakki tersebut, Geoch (dalam Suprijono, 2011:2) learning is change in performance as a result of practice yaitu belajar merupakan perubahan performance sebagai Prestasi latihan. Setelah memahami pengertian belajar, perlu diketahui tentang halnya prinsip belajar. Suprijono (2011:4) Prinsip belajar terdiri dari beberapa hal yaitu :

1. Perubahan tingkah laku

2. Belajar merupakan proses

3. Belajar merupakan bentuk pengalaman

Selaras dengan dua pendapat sebelumnya, terkait dengan belajar Slameto (2010:2) mengartikan bahwa belajar merupakan suatu proses perubahan yaitu perubahan tingkah laku sebagai Prestasi dari interaksi 
dengan lingkungannya dalam memenuhi kebutuhan hidupnya. Sehingga dapat disimpulkan bahwa belajar adalah proses usaha yang dilakukan

Berdasarkan uraian tersebut di atas, maka artikel ini merupakan hasil dari penelitian yang penulis lakukan pada tahun 2018 tentang dampak mahasiswa prodi ilmu falak yang telah mengambil mata kuliah praktikum hisab awal waktu salat dan arah kiblat pada semester gasal 2017/2018 terhadap pelaksanaan salatnya.

\section{RUMUSAN MASALAH}

Berangkat dari judul artikel ini yaitu "Dampak Perkuliahan Praktikum Hisab Awal Waktu Salat dan Arah Kiblat Terhadap Kehidupan Beragama Mahasiswa", maka sebelum merumuskan masalah, menurut penulis perlu untuk dijelaskan terlebih dahulu tentang definisi operasional terkait judul tersebut, sehingga diharapkan akan diperoleh pemahaman yang sama antara penulis dengan pembaca terkait judul tersebut.

Adapun definisi operasional yang penulis tetapkan yaitu

1. Dampak

Guna mengetahui dampak, maka penulis akan menggunakan teori terkait ini yaitu melakukan sebuah evaluasi atas sebuah perkuliahan yang telah dilaksanakan. Adapun redaksi operasional yang digunakan yaitu pengaruh.
2. Perkuliahan Praktikum Hisab Awal Waktu Salat dan Arah Kiblat

Terkait dengan mata kuliah ini, maka jika direlasikan dengan kata evaluasi pada definisi operasional pada bagian pertama tadi, akan diperoleh pemahaman bahwa evaluasi yang dimaksud yaitu evaluasi tentang hasil belajar mahasiswa dalam perkuliahan perkuliahan praktikum hisab awal waktu salat dan arah kiblat

3. Kehidupan beragama mahasiswa Kehidupan beragama mahasiswa yang penulis maksud di sini yaitu tentang pelaksanaan salat mahasiswa.

Selaras dengan pengertian yang penulis jelaskan dalam definisi operasional tersebut di atas, maka rumusan masalah yang penulis tetapkan yaitu bagaimana Dampak mata kuliah praktikum hisab awal waktu salat dan arah kiblat terhadap pelaksanaan salat mahasiswa?

\section{KAJIAN PUSTAKA}

1. Mata kuliah praktikum Awal waktu salat dan Arah kiblat

Mata kuliah praktikum Awal waktu salat dan Arah kiblat merupakan mata kuliah yang ada dalam prodi IImu Falak FSH UINSA dengan bobot dua SKS, yang oleh prodi ilmu falak ditawarkan pada semester tiga. Tahun akademik 2017/2018 sebagaiamana dalam siakad UINSA dan penulis diamanahi untuk menjadi 
pengampu mata kuliah ini. Pelaksanaan perkuliahan mata kuliah ini dilaksanakan dengan jumlah pertemuan sebanyak 14 kali pertemuan dengan satu kali ujian tengah semester dan satu kali ujian akhir semester, sehingga jumlah untuk tatap mukanya terkait teori yaitu 12 kali tatap muka.

Berdasarkan

RPS

perkuliahan yang diamanahkan prodi, secara umum indikator target keberhasilan perkuliahan ini yaitu setelah perkuliahan ini, mahasiswa diharapkan memahami tentang praktik penentuan awal waktu salat dan arah kiblat. Dengan bahasa lain, dalam teori belajar dan pembelajaran, maka mata kuliah ini dalam empat pilar belajar UNESCO dikategorikan dalam pilar belajar untuk melakukani (learn to do).

2. Pelaksanaan Salat

Sebagaimana diuraikan dalam latar belakang bahwa dalam pelaksanaan salat ada dua hal yang tidak bisa dilepaskan yaitu waktu salat dan arah kiblat. Dua hal ini yang dipelajari dalam mata kuliah praktikum Hisab Awal waktu salat dan Arah kiblat. Selaras dengan itu, dampak yang dimaksud setelah proses perkuliahan terhadap pelaksanaan salat yaitu secara sederhana dapat dipahami bahwa ada perubahan pada diri mahasiswa ketika sebelum dan sesudah perkuilahan.ini berlangsung Adapun dampak yang dimaksud yaitu terkait dengan sikap mahasiswa ketika akan menjalankan salat.

\section{METODE PENELITIAN/ LANDASAN}

TEORI

Guna menjawab rumusan masalah yang penulis tetapkan, maka penulis menetapkan penelitian yang dilakukan yaitu penelitian deskriptif kuantitatif, dikarenakan penelitian ini menganalisis pelaksanaan salat terkait dengan waktu salat dan arah kiblat yang dikerjakan oleh mahasiswa. Serta mendeskripsikan berapa besar dampak perkuliahan tersebut pada pelaksanaan salat mahasiswa.

Berikut ini akan diuraikan tentang obyek penelitian, metode pengumpulan data, dan analisis data.

1. Obyek penelitian

Obyek penlitian ini yaitu mahasiswa prodi ilmu falak fakultas syariah dan hukum UINSA yang pada tahun akademik 2017/2018 mengambil mata kuliah praktikum hisab awal waktu salat dan arah kiblat yang penulis ampu. Dengan jumlah peserta 29 mahasiswa yang terdiri dari 12 mahasiswa perempuan dan 17 mahasiswa laki-laki.

2. Teknik Pengumpulan Data Pengumpulan data yang dilakukan oleh penulis yaitu 
dengan cara melaui angket

Adapun daftar pertanyaan yang

tentang praktikum hisab awal dalam angket yang digunakan

waktu salat dan arah kiblat.

ditunjukkan pada tabel 1 berikut:

Tabel 1. Daftar Pertanyaan Angket

\begin{tabular}{|c|c|c|c|}
\hline No & Soal & $\mathrm{Ya}$ & Tidak \\
\hline 1 & $\begin{array}{l}\text { Sebelum mengikuti mata kuliah praktikum Falak } 1 \text { (waktu salat dan } \\
\text { arah kiblat), saya kurang memahami tentang sejarah dan dasar hukum } \\
\text { arah kiblat. }\end{array}$ & & \\
\hline 2 & $\begin{array}{l}\text { Sebelum mengikuti mata kuliah praktikum Falak } 1 \text { (waktu salat dan } \\
\text { arah kiblat), saya kurang memahami tentang tata cara penentuan dan } \\
\text { perhitungan arah kiblat. }\end{array}$ & & \\
\hline 3 & $\begin{array}{l}\text { Setelah mengikuti mata kuliah praktikum Falak } 1 \text { (waktu salat dan arah } \\
\text { kiblat), saya mengteahui, mengerti, dan memahami tentang } \\
\text { perhitungan arah kiblat. }\end{array}$ & & \\
\hline 4 & $\begin{array}{l}\text { Setelah mengikuti mata kuliah praktikum Falak } 1 \text { (waktu salat dan arah } \\
\text { kiblat), saya mengetahui, mengerti, dan memahami tentang tata cara } \\
\text { pengukuran arah kiblat. }\end{array}$ & & \\
\hline 5 & $\begin{array}{l}\text { Setelah mengikuti mata kuliah praktikum Falak } 1 \text { (waktu salat dan arah } \\
\text { kiblat),, saya terkadang merasa ragu-ragu terkait arah kiblat tempat } \\
\text { salat yang baru saya temui. }\end{array}$ & & \\
\hline 6 & $\begin{array}{l}\text { Sebelum mengikuti mata kuliah praktikum Falak } 1 \text { (waktu salat dan } \\
\text { arah kiblat), saya kurang memahami tentang sejarah dan dasar hukum } \\
\text { waktu salat. }\end{array}$ & & \\
\hline 7 & $\begin{array}{l}\text { Sebelum mengikuti mata kuliah praktikum Falak } 1 \text { (waktu salat dan } \\
\text { arah kiblat), saya kurang memahami tentang tata cara penentuan dan } \\
\text { perhitungan waktu salat. }\end{array}$ & & \\
\hline 8 & $\begin{array}{l}\text { Setelah mengikuti mata kuliah praktikum Falak } 1 \text { (waktu salat dan arah } \\
\text { kiblat), saya mengteahui, mengerti, dan memahami tentang } \\
\text { perhitungan waktu salat. }\end{array}$ & & \\
\hline 9 & $\begin{array}{l}\text { Setelah mata kuliah praktikum Falak } 1 \text { (waktu salat dan arah kiblat), } \\
\text { saya mengetahui, mengerti, dan memahami tentang fenomena alam } \\
\text { terkait waktu salat. }\end{array}$ & & \\
\hline 10 & $\begin{array}{l}\text { Setelah mata kuliah praktikum Falak } 1 \text { (waktu salat dan arah kiblat), } \\
\text { saya terkadang merasa ragu-ragu terkait jadwal waktu salat yang baru } \\
\text { saya temui }\end{array}$ & & \\
\hline
\end{tabular}

Berdasarkan 10 pertanyaan yang ada dalam angket tersebut, dapat disimpulkan bahwa pertanyaan no 1 sampai 5 terkait dengan arah kiblat. Sedangkan pertanyaan nomor 6 sampai 10 terkait dengan waktu salat.

3. Teknik Analisis Data

Setelah data dikumpulkan, maka selanjutnya data penulis analisis dengan cara menghitung prosentase setiap soal yang ada dalam angket, dari hitungan tersebut selanjutnya akan penulis dikripsikan. Dengan ketentuan kode pilihan jawaban, jika 1 berarti memilih $\mathrm{Ya}$, sedangkan 0 berati memilih tidak.

Berdasarkan teknik analisis data yang telah penulis tetapkan 
tersebut, maka langkah ini sejalan dengan yang disampaikan oleh Subagyo (2012:2) dapat digolongkan dalam statistik deskriptif.

\section{PEMBAHASAN}

Sebagaimana telah dijelaskan penulis tentang teknik analisis data yang penulis lakukan yaitu dimulai dengan menghitung prosentase setiap soal yang ada dalam angket, dari hitungan tersebut selanjutnya akan penulis dikripsikan, maka hasil angket dari mahasiswa yang telah diisi oleh mahasiswa yang menjadi obyek penelitian ditunjukkan pada tabel 2 .

Tabel 2. Hasil Angket Mahasiswa

\begin{tabular}{|c|l|c|c|c|c|c|c|c|c|c|c|}
\hline \multirow{2}{*}{ NO } & \multirow{2}{*}{ NAMA } & \multicolumn{7}{|c|}{ PILIHAN ANGKET SOAL NOMOR } \\
\cline { 2 - 12 } & & 1 & 2 & 3 & 4 & 5 & 6 & 7 & 8 & 9 & 10 \\
\hline 1 & Mahasiswa 1 & 1 & 0 & 1 & 0 & 1 & 1 & 1 & 1 & 1 & 0 \\
\hline 2 & Mahasiswa 2 & 0 & 1 & 0 & 1 & 1 & 1 & 0 & 1 & 1 & 1 \\
\hline 3 & Mahasiswa 3 & 1 & 1 & 1 & 1 & 0 & 1 & 1 & 1 & 1 & 0 \\
\hline 4 & Mahasiswa 4 & 1 & 1 & 1 & 1 & 0 & 1 & 1 & 1 & 1 & 0 \\
\hline 5 & Mahasiswa 5 & 1 & 1 & 1 & 1 & 1 & 1 & 1 & 1 & 1 & 0 \\
\hline 6 & Mahasiswa 6 & 1 & 1 & 1 & 1 & 0 & 1 & 1 & 1 & 1 & 1 \\
\hline 7 & Mahasiswa 7 & 1 & 1 & 1 & 1 & 1 & 1 & 1 & 1 & 1 & 1 \\
\hline 8 & Mahasiswa 8 & 0 & 0 & 0 & 1 & 1 & 1 & 0 & 0 & 0 & 1 \\
\hline 9 & Mahasiswa 9 & 0 & 1 & 1 & 1 & 0 & 0 & 1 & 1 & 1 & 0 \\
\hline 10 & Mahasiswa 10 & 1 & 1 & 1 & 0 & 0 & 1 & 1 & 1 & 0 & 0 \\
\hline 11 & Mahasiswa 11 & 1 & 1 & 1 & 1 & 0 & 1 & 1 & 1 & 1 & 1 \\
\hline 12 & Mahasiswa 12 & 1 & 1 & 1 & 1 & 1 & 1 & 1 & 1 & 1 & 1 \\
\hline 13 & Mahasiswa 13 & 1 & 0 & 1 & 0 & 1 & 0 & 0 & 1 & 0 & 0 \\
\hline 14 & Mahasiswa 14 & 1 & 1 & 1 & 1 & 1 & 1 & 1 & 1 & 1 & 1 \\
\hline 15 & Mahasiswa 15 & 1 & 1 & 1 & 0 & 1 & 1 & 1 & 1 & 1 & 1 \\
\hline 16 & Mahasiswa 16 & 0 & 0 & 1 & 1 & 0 & 1 & 0 & 0 & 1 & 0 \\
\hline 17 & Mahasiswa 17 & 1 & 0 & 1 & 1 & 1 & 1 & 1 & 0 & 0 & 1 \\
\hline 18 & Mahasiswa 18 & 0 & 0 & 1 & 1 & 1 & 1 & 1 & 1 & 1 & 1 \\
\hline 19 & Mahasiswa 19 & 1 & 1 & 1 & 0 & 0 & 1 & 1 & 1 & 1 & 0 \\
\hline 20 & Mahasiswa 20 & 1 & 1 & 0 & 1 & 0 & 0 & 1 & 0 & 0 & 0 \\
\hline 21 & Mahasiswa 21 & 1 & 1 & 1 & 1 & 1 & 1 & 1 & 1 & 1 & 0 \\
\hline 22 & Mahasiswa 22 & 1 & 1 & 1 & 1 & 1 & 1 & 1 & 1 & 1 & 1 \\
\hline 23 & Mahasiswa 23 & 1 & 1 & 1 & 1 & 1 & 1 & 1 & 1 & 1 & 1 \\
\hline 24 & Mahasiswa 24 & 1 & 1 & 1 & 0 & 0 & 1 & 1 & 1 & 1 & 1 \\
\hline 25 & Mahasiswa 25 & 1 & 1 & 1 & 1 & 1 & 1 & 1 & 1 & 1 & 1 \\
\hline 26 & Mahasiswa 26 & 0 & 1 & 1 & 1 & 1 & 0 & 1 & 1 & 1 & 1 \\
\hline 27 & Mahasiswa 27 & 1 & 1 & 0 & 1 & 0 & 0 & 1 & 1 & 1 & 0 \\
\hline
\end{tabular}

Terkait dengan data tersebut di atas, selanjutnya penulis analisis satu persatu sesuai dengan urutan nomor soal dalam angket.
1. Analisis pertanyaan pertama dalam angket

Pertanyaan pertama dalam angket yaitu Sebelum mengikuti 
mata kuliah praktikum Falak 1 (waktu salat dan arah kiblat), saya kurang memahami tentang sejarah dan dasar hukum arah kiblat. Berdasarkan data yang diperoleh bahwa

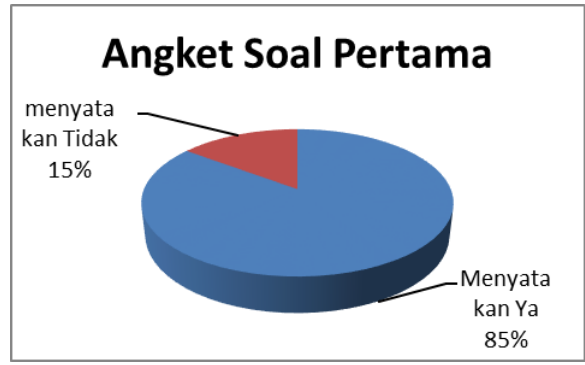

Gambar 1. Diagram Lingkaran angket soal pertama

Berdasarkan diagram tersebut diperoleh sebuah fakta bahwa $\quad 78 \%$ mahasiswa menyatakan bahwa Sebelum mengikuti mata kuliah praktikum Falak 1 (waktu salat dan arah kiblat), saya kurang memahami tentang sejarah dan dasar hukum arah kiblat. Sehingga dengan demikian, makna tersirat data ini yaitu bahwa mata kuliah ini memberikan dampak yang besar tentang pengetahuan tentang sejarah dan dasar hukum arah kiblat bagi mahasiswa.

2. Analisis pertanyaan kedua dalam angket

Pertanyaan kedua dalam angket yaitu Sebelum mengikuti mata kuliah praktikum Falak 1 (waktu salat dan arah kiblat), saya kurang memahami tentang tata cara penentuan dan perhitungan arah kiblat. Berdasarkan data angket yang telah diisi mahasiswa diperoleh bahwa

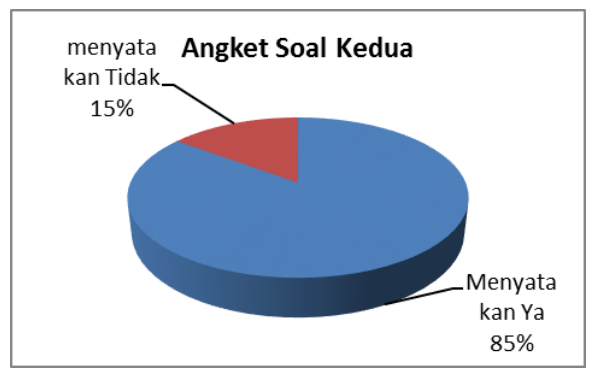

Gambar 2. Diagram Lingkaran angket soal kedua

Berdasarkan diagram tersebut diperoleh sebuah fakta bahwa $\quad 78 \%$ mahasiswa menyatakan bahwa Sebelum mengikuti mata kuliah praktikum Falak 1 (waktu salat dan arah kiblat), kurang memahami tentang tata cara penentuan dan perhitungan arah kiblat. Selaras dengan data analisis pertama, bahwa mata kuliah ini juga memberikan dampak yang besar tentang pengetahuan tentang perhitungan dan penentuan arah kiblat bagi mahasiswa.

3. Analisis pertanyaan ketiga dalam angket

Pertanyaan ketiga dalam angket yaitu Setelah mengikuti mata kuliah praktikum Falak 1 (waktu salat dan arah kiblat), saya mengteahui, mengerti, dan memahami tentang perhitungan arah kiblat. Berdasarkan data 
angket yang telah diisi mahasiswa diperoleh bahwa

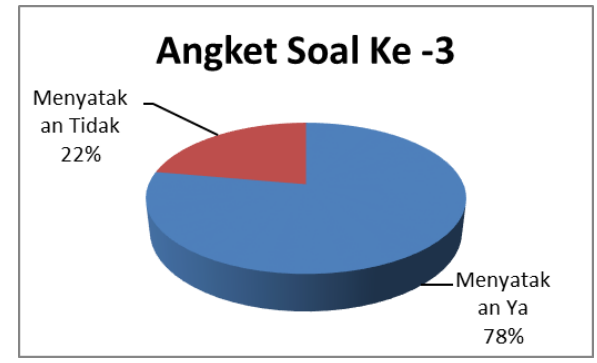

Gambar 3. Diagram Lingkaran angket soal ketiga

Berdasarkan diagram tersebut diperoleh sebuah fakta bahwa $\quad 85 \%$ mahasiswa menyatakan bahwa Setelah mengikuti mata kuliah praktikum Falak 1 (waktu salat dan arah kiblat), mahasiswa mengteahui, mengerti, dan memahami tentang perhitungan arah kiblat, data ini selaras dengan hasil analisis pada angket soal nomor dua, yang mata kuliah ini memberikan dampak yang besar tentang pengetahuan tentang perhitungan arah kiblat bagi mahasiswa.

4. Analisis pertanyaan keempat dalam angket

Pertanyaan keempat dalam angket yaitu Setelah mengikuti mata kuliah praktikum Falak 1 (waktu salat dan arah kiblat), saya mengetahui, mengerti, dan memahami tentang tata cara pengukuran arah kiblat. Berdasarkan data angket yang telah diisi mahasiswa diperoleh bahwa

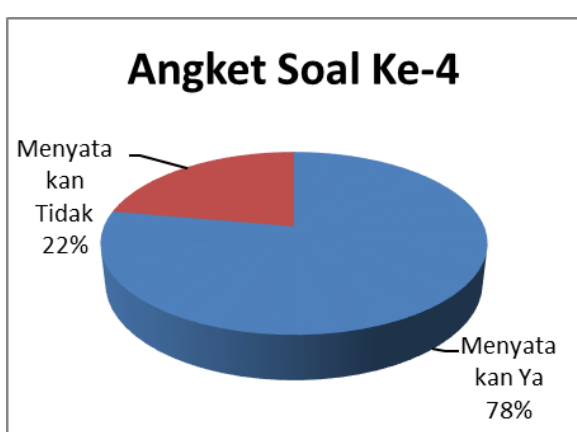

Gambar 4. Diagram Lingkaran angket soal keempat

Berdasarkan diagram tersebut diperoleh sebuah fakta bahwa $78 \%$ mahasiswa menyatakan bahwa Setelah mengikuti mata kuliah praktikum Falak 1 (waktu salat dan arah kiblat), mahasiswa menjadi mengetahui, mengerti, dan memahami tentang tata cara pengukuran arah kiblat, data ini selaras dengan hasil analisis pada angket soal nomor dua, yang mata kuliah ini memberikan dampak yang besar tentang pengetahuan tentang pengukuran arah kiblat bagi mahasiswa.

5. Analisis pertanyaan kelima dalam angket

Pertanyaan kelima dalam angket yaitu Setelah mengikuti mata kuliah praktikum Falak 1 (waktu salat dan arah kiblat),, saya terkadang merasa ragu-ragu terkait arah kiblat tempat salat yang baru saya temui. Berdasarkan data angket yang telah diisi mahasiswa diperoleh bahwa 


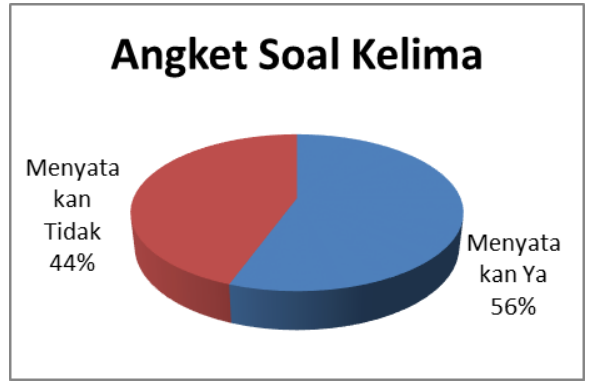

Gambar 5. Diagram Lingkaran angket soal kelima

Berdasarkan diagram tersebut diperoleh sebuah fakta bahwa $59 \%$ mahasiswa menyatakan bahwa Setelah mengikuti mata kuliah praktikum Falak 1 (waktu salat dan arah kiblat), mahasiswa terkadang merasa ragu-ragu terkait arah kiblat tempat salat yang baru saya temui. Hal ini menunjukkan bahwa mata kuliah ini berdampak pada sikap keberagamaan mahasiswa dalam masalah arah kiblat yaitu sikap untuk percaya akan arah kiblat yang ada di masjid yang baru ditemui.

6. Analisis pertanyaan keenam dalam angket

Pertanyaan keenam dalam angket yaitu Sebelum mengikuti mata kuliah praktikum Falak 1 (waktu salat dan arah kiblat), saya kurang memahami tentang sejarah dan dasar hukum waktu salat. Berdasarkan data angket yang telah diisi mahasiswa diperoleh bahwa

\section{Soal Angket Keenam}

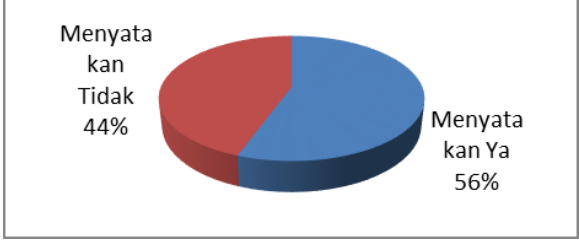

Gambar 6. Diagram Lingkaran angket soal keenam

Berdasarkan diagram tersebut diperoleh sebuah fakta bahwa $\quad 81 \%$ mahasiswa menyatakan bahwa Sebelum mengikuti mata kuliah praktikum Falak 1 (waktu salat dan arah kiblat), saya kurang memahami tentang sejarah dan dasar hukum waktu salat. Hal ini menunjukkan bahwa mata kuliah ini berdampak cukup besar pada pengetahuan mahasiswa terkait dengan sejarah dan dasar hukum waktu salat

7. Analisis pertanyaan ketujuh dalam angket

Pertanyaan ketujuh dalam angket yaitu Sebelum mengikuti mata kuliah praktikum Falak 1 (waktu salat dan arah kiblat), saya kurang memahami tentang tata cara penentuan dan perhitungan waktu salat. Berdasarkan data angket yang telah diisi mahasiswa diperoleh bahwa 


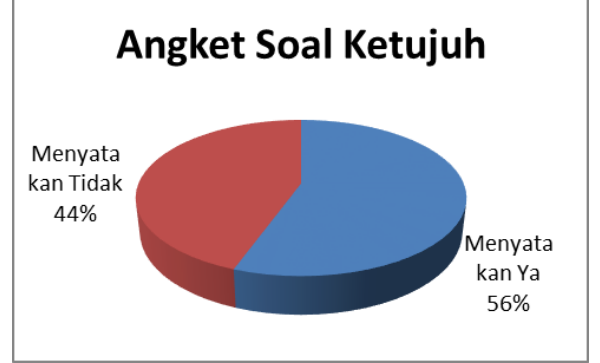

Gambar 7. Diagram Lingkaran angket soal ketujuh

Berdasarkan diagram tersebut diperoleh sebuah fakta bahwa $85 \%$ mahasiswa menyatakan Sebelum mengikuti mata kuliah praktikum Falak 1 (waktu salat dan arah kiblat), kurang memahami tentang tata cara penentuan dan perhitungan waktu salat. Hal ini selaras dengan data pada angket yang keeenam yang menunjukkan bahwa mata kuliah ini berdampak cukup besar pada pengetahuan mahasiswa terkait dengan sejarah dan dasar hukum waktu salat

8. Analisis pertanyaan kedelapan dalam angket

Pertanyaan kedelapan dalam angket yaitu Setelah mengikuti mata kuliah praktikum Falak 1 (waktu salat dan arah kiblat), saya mengteahui, mengerti, dan memahami tentang perhitungan waktu salat. Berdasarkan data angket yang telah diisi mahasiswa diperoleh bahwa

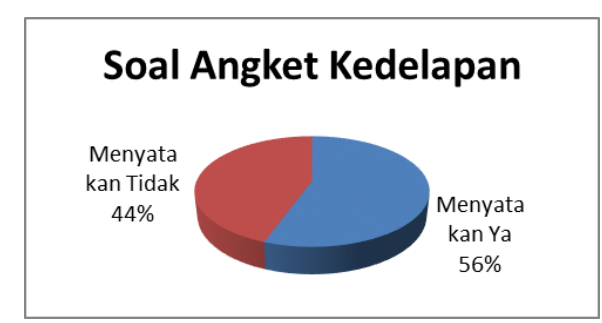

Gambar 8. Diagram Lingkaran angket soal kedelapan

Berdasarkan diagram tersebut diperoleh sebuah fakta bahwa $\quad 85 \% \quad$ mahasiswa menyatakan Setelah mengikuti mata kuliah praktikum Falak 1 (waktu salat dan arah kiblat), smengteahui, mengerti, dan memahami tentang perhitungan waktu salat. Hal ini selaras dengan data pada angket yang keeenam dan ketujuh yang menunjukkan bahwa mata kuliah ini berdampak cukup besar pada pengetahuan mahasiswa terkait dengan sejarah dan dasar hukum waktu salat.

9. Analisis pertanyaan kesembilan dalam angket

Pertanyaan kesembilan dalam angket yaitu Setelah mata kuliah praktikum Falak 1 (waktu salat dan arah kiblat), saya mengetahui, mengerti, dan memahami tentang fenomena alam terkait waktu salat. Berdasarkan data angket yang telah diisi mahasiswa diperoleh bahwa 


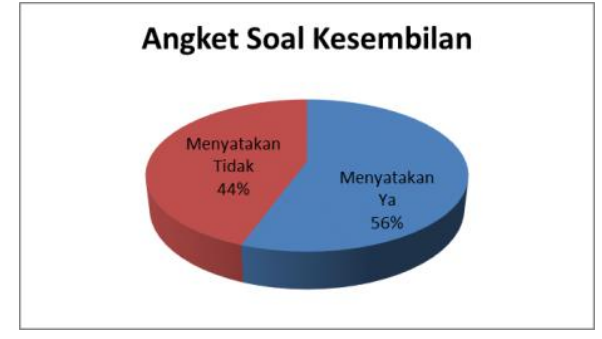

Gambar 9. Diagram Lingkaran angket soal kesembilan

Berdasarkan diagram tersebut diperoleh sebuah fakta bahwa $\quad 85 \%$ mahasiswa menyatakan Setelah mata kuliah praktikum Falak 1 (waktu salat dan arah kiblat), mengetahui, mengerti, dan memahami tentang fenomena alam terkait waktu salat. Hal ini selaras dengan data pada angket yang keeenam, ketujuh, dan kedelapan yang menunjukkan bahwa mata kuliah ini berdampak cukup besar pada pengetahuan mahasiswa terkait dengan sejarah dan dasar hukum waktu salat.

10. Analisis pertanyaan kesepuluh dalam angket

Pertanyaan kesepuluh dalam angket yaitu Setelah mata kuliah praktikum Falak 1 (waktu salat dan arah kiblat), saya terkadang merasa ragu-ragu terkait jadwal waktu salat yang baru saya temui. Berdasarkan data angket yang telah diisi mahasiswa diperoleh bahwa

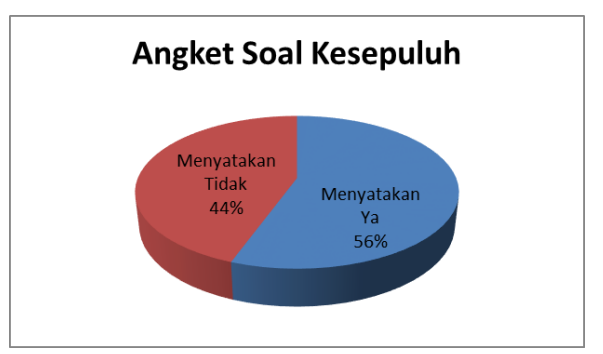

Gambar 9. Diagram Lingkaran angket soal kesembilan

\begin{abstract}
Berdasarkan diagram tersebut diperoleh sebuah fakta bahwa $\quad 56 \%$ mahasiswa menyatakan bahwa Setelah mata kuliah praktikum Falak 1 (waktu salat dan arah kiblat), saya terkadang merasa ragu-ragu terkait jadwal waktu salat yang baru saya temui. Hal ini menunjukkan bahwa mata kuliah ini berdampak pada sikap keberagamaan mahasiswa dalam masalah arah kiblat yaitu sikap untuk percaya pada jadwal waktu salat yang baru saya temui.
\end{abstract}

\section{KESIMPULAN}

Berdasarkan uraian yang telah dilakukan pada tahap-tahap sebelumnya dapat diperoleh sebuah kesimpulan bahwa dampak perkuliahan praktikum hisab awal waktu salat dan arah kiblat terhadap kehidupan beragama mahasiswa paling dominan berdampak dalam wilayah pengetahuan, hal ini bisa dilihat dalam analisis pada angket soal nomor 1, 2, 3, 4, 6, 7. 8. Dan 9. Sedangkan dalam wilayah pelaksanaan dalam kehidupan seharihari memberikan dampak, yang tidak 
begitu kuat seperti dalam wilayah pengetahuan, hal ini bisa dilihat dalam angket soal nomor 5 dan 10 .

\section{DAFTAR PUSTAKA}

Departemen Agama RI, 2005, AlQurian dan terjemahnya, Bandung: JUMẤNATUL 'ALĪ-ART

Ibn Khuzaimah, 1970, Sahih Ibn Khuzaimah, Baeirut: Beirut: Al Maktab Al Islam.

Kusdiono, 2002, Ilmu Ukur Segitiga Bola, Bandung: Jurusan teknik geodesi, Institut Teknologi Bandung.

Muzakki. 2015. Instrumentasi Nilai Dalam Pembelajaran Perspektif Sosiologi Pendidikan Karakter. Surabaya: Adea Pustaka

Nawawi, Abd. Salam. 2010. Ilmu Falak Cara Praktis Menghitung Waktu Salat, Arah kiblat, dan Awal Bulan. Sidoarjo: Aqoba

Subagyo, Pangetu. 2012. Statistik Deskriptif. Yogyakarta : BPFE

Slameto. 2003. Belajar dan FaktorFaktor yang Mempengaruhinya. Jakarta: Rineka Cipta.

Suprijono, Agus. 2011. Cooperatif Learning Teori dan Aplikasi PAIKEM. Yogyakarta: Pustaka pelajar 